\title{
Sex differences in human adipose tissues - the biology of pear shape
}

\author{
Kalypso Karastergiou', Steven R Smith², Andrew S Greenberg ${ }^{3}$ and Susan K Fried ${ }^{1,4^{*}}$
}

\begin{abstract}
Women have more body fat than men, but in contrast to the deleterious metabolic consequences of the central obesity typical of men, the pear-shaped body fat distribution of many women is associated with lower cardiometabolic risk. To understand the mechanisms regulating adiposity and adipose tissue distribution in men and women, significant research attention has focused on comparing adipocyte morphological and metabolic properties, as well as the capacity of preadipocytes derived from different depots for proliferation and differentiation. Available evidence points to possible intrinsic, cell autonomous differences in preadipocytes and adipocytes, as well as modulatory roles for sex steroids, the microenvironment within each adipose tissue, and developmental factors. Gluteal-femoral adipose tissues of women may simply provide a safe lipid reservoir for excess energy, or they may directly regulate systemic metabolism via release of metabolic products or adipokines. We provide a brief overview of the relationship of fat distribution to metabolic health in men and women, and then focus on mechanisms underlying sex differences in adipose tissue biology.
\end{abstract}

Keywords: Adipocyte, Fat distribution, Lipolysis, Fatty acid uptake

\section{Review}

Women, compared to men, have higher percent body fat and deposit it in a different pattern, with relatively more adipose tissue in the hips and thighs. This 'female' fat distribution, independent of total body fat, confers protection against metabolic diseases, such as type 2 diabetes and atherosclerosis [1]. Although sex differences in fat distribution and correlations to metabolic health are well established in the clinical and epidemiological literatures $[1,2]$, the biological underpinnings of these associations remain poorly understood. Microarray analyses show that adipose mass and depot differences in adipose tissue gene expression in mice are regulated by sexually dimorphic gene networks. Inflammatory and developmental genes, some of which are modulated by sex steroid hormones, are prominent among depot- and sexspecific genes [3-5]. Furthermore, and especially important for understanding the pathogenesis of obesity and

\footnotetext{
* Correspondence: skfried@bu.edu

'Department of Medicine, Section of Endocrinology, Diabetes \& Nutrition, Boston University School of Medicine, Boston, MA, USA

${ }^{4}$ Division of Endocrinology, Diabetes, and Nutrition, Department of Medicine, Boston University, School of Medicine, 650 Albany St, EBRC-810, Boston, MA 02118, USA

Full list of author information is available at the end of the article
}

its metabolic complications, interactions of sex differences in gene expression with environmental variables such as diet composition and exercise/activity on fatness and fat distribution remain largely unexplored. Because excellent reviews of sex differences in the regulation of food intake and body weight have been recently published [6,7], in this review, we focus on physiologic and genetic determinants of sex differences in fat distribution.

\section{The adipose organ of humans}

Cinti convincingly argues that body fat is stored in the adipose organ which consists of definable fat depots [8]. Subcutaneous white adipose tissue (SAT) depots, just under the skin, store $\sim 80-90 \%$ of total body fat, mainly in the abdominal (around the waist), subscapular (on the upper back), gluteal and femoral (thigh) areas. These subcutaneous adipose tissues have distinct morphological and metabolic profiles and exhibit sex-specific differences in size and function that we will review in detail. Intraabdominal depots include visceral adipose tissues (VAT, omental and mesenteric), which are associated with digestive organs. VATs drain their blood into the portal vein and account for $6-20 \%$ of total body fat, with higher values in males than females [9-12]. Adipose tissues in the

\section{Biomed Central}

(c) 2012 Karastergiou et al; licensee BioMed Central Ltd. This is an Open Access article distributed under the terms of the Creative Commons Attribution License (http://creativecommons.org/licenses/by/2.0), which permits unrestricted use, distribution, and reproduction in any medium, provided the original work is properly cited. 
retroperitoneal compartment ( $7 \%$ of total [13]) do not drain into the portal vein and are therefore not considered 'visceral'.

It has been recently recognized that humans, even in adulthood, possess islands of brown adipose tissue, mainly in the supraclavicular/dorsal cervical area $[14,15]$. Whereas the function of white adipose tissues is to store excess energy, the function of brown fat is to produce heat. Indeed brown fat mass and activity are induced by cold stress [16]. The exact role of this specialized tissue in the regulation of energy balance in humans remains to be determined ([16], and reviewed in [17]). Of interest with regard to sex differences in metabolism, limited data indicate that women tend to have higher quantities of brown fat, but the significance of this observation is not clear, as women do not have higher energy expenditure (adjusted for lean mass) $[14,15,18]$. The regulation of brown adipose tissue mass and function in determining susceptibility to obesity in men and women is currently an active and important area of investigation, but little is known. This review will focus on sex differences in human white adipose tissues.

\section{Determinants of sex differences in body fat and fat distribution}

For the same body mass index (BMI), women typically present with $\sim 10 \%$ higher body fat compared to men $[19,20]$. Aging increases adiposity in both sexes, but again, women are characterized by higher percent body fat throughout the entire life span [21]. Sex x race interactions are also evident: in contrast to Caucasians, African American women and men appear to have comparable fat content at higher BMI levels [22].

At comparable levels of total adiposity (estimated either from BMI or by imaging techniques), women have more SAT both in the abdominal [22-25] and in the gluteofemoral area [26,27]. Moreover, this is due to preferential increase of superficial and not deep SAT in women; it is the size of the deep compartment that is inversely associated with fasting insulin levels [28]. At the same time women are characterized by lower intra-abdominal/visceral fat mass [23-25]. However, the difference in visceral fat mass is diminished and not consistently seen in older age groups [22,29]. Women of Asian origin, either Chinese or South Asian, have higher VAT content than Caucasian women (BMI-adjusted), but lower than men of the same ethnicity [30]. Only black women have VAT comparable to and at the same time abdominal SAT larger than black men [24,27].

\section{Fat distribution is modulated by sex steroids}

Striking sex differences arise during puberty: the increase in body weight in boys is primarily due to increases in lean mass whereas in girls due to increases in fat mass; typical android and gynoid fat distributions also appear for the first time during this time period [31-33]. Menopause is followed by redistribution of adipose tissue towards a more central/android phenotype [34,35]. Importantly, it is visceral adiposity that rises in women during the peri-menopausal transition, presumably due to the fall in estrogen levels [36,37]. As testosterone declines with age, visceral adiposity also increases in men [38,39]. The hyperandrogenism in women with polycystic ovary syndrome is frequently, but not consistently, associated with increased total and abdominal adiposity [40-42]. Finally, studies of transgendered men and women treated with sex steroids show clear shifts in fat distribution [43]. Very little is understood about the cellular and molecular mechanisms by which sex steroids modulate the growth and metabolism and hence the size of specific fat depots in humans (as reviewed below).

\section{Genetic determinants of total adiposity and distribution in women and men}

Twin studies demonstrate that genetic factors account for up to $70 \%$ of the BMI variance [44], and that this effect is influenced by sex [45]. A few rare genetic syndromes have differential effects on total adiposity in males and females and may provide clues to understanding sex differences in adiposity [46-49]. A number of polymorphisms in the estrogen receptor $\alpha$ gene are associated with total adiposity and fat distribution and in some cases this relationship is restricted to females [50-52]. Results of recent genomewide association studies (GWAS) have identified genetic determinants of common polygenic obesity that interact with environmental variables in complex ways, but so far explain only a small percentage of the inter-individual variation in BMI [53].

GWAS and meta-analyses of GWAS have also identified novel loci associated with central or peripheral fat distribution, some of which are sex-specific (summarized in Table 1) [54,55]. For five of these loci (near or in RSPO3, TBX15, ITPR2, WARS2 and STAB1), differential mRNA expression is also noted between abdominal and gluteal tissue [54]. Although the functional correlates of these SNPs are yet to be identified, there are a number of intriguing candidates. For example, VEGF plays an important role in the vascularization of the expanding adipose tissue in development or obesity [56]; GRB-14 inhibits insulin action [57,58]; TFAP2B affects adipokine secretion and adipocyte insulin sensitivity $[59,60]$ and TBX15 differentiation and lipid accumulation [61]. Both KREMEN1 and RSPO3 interact with the Wnt signaling pathway, which in turn plays a fundamental role in adipocyte differentiation [62,63].

These loci explain in total only $1.34 \%$ of the variance in waist-to-hip ratio in women, and even less $(0.46 \%)$ in 
Table 1 Single nucleotide polymorphisms (SNPs) associated with fat distribution in genome-wide association studies

\begin{tabular}{|c|c|c|c|c|c|}
\hline SNP & Nearby gene & $\begin{array}{l}\text { Associated } \\
\text { with }\end{array}$ & $\begin{array}{l}\text { Significant in } \\
\text { men }\end{array}$ & $\begin{array}{l}\text { Significant in } \\
\text { women }\end{array}$ & $\begin{array}{l}\text { Significant sex } \\
\text { difference }\end{array}$ \\
\hline rs9491696 & RSPO3 (R-spondin 3) & WHR & Yes & Yes & Yes \\
\hline rs6905288 & VEGFA (vascular endothelial growth factor A) & WHR & Yes & Yes & Yes \\
\hline rs2605100 & LYPLAL1 (lysophospholipase-like protein 1) & WHR & No & Yes & Yes \\
\hline rs4846567 & & WHR & No & Yes & Yes \\
\hline rs718314 & $\begin{array}{l}\text { ITPR2 (inositol 1,4,5-triphosphate receptor 2) - } \\
\text { SSPN (sarcospan) }\end{array}$ & WHR & Yes & Yes & Yes \\
\hline rs1443512 & HOXC13 (homeobox C13) & WHR & Yes & Yes & Yes \\
\hline rs4823006 & $\begin{array}{l}\text { ZNRF3 (zinc and ring finger 3) - KREMEN1 } \\
\text { (kringle containing transmembrane protein 1) }\end{array}$ & WHR & Yes & Yes & Yes \\
\hline rs10195252 & GRB14 (growth factor receptor-bound protein 14) & WHR & Borderline & Yes & Yes \\
\hline rs6795735 & $\begin{array}{l}\text { ADAMTS9 (ADAM metallopeptidase with } \\
\text { thrombospondin type } 1 \text { motif, 9) }\end{array}$ & WHR & Borderline & Yes & Yes \\
\hline rs984222 & $\begin{array}{l}\text { TBX15 (T-box 15) - WARS2 (tryptophanyl tRNA } \\
\text { synthetase 2, mitochondrial) }\end{array}$ & WHR & Yes & Yes & No \\
\hline rs1055144 & NFE2L3 [nuclear factor (erythroid-derived 2)-like 3] & WHR & Yes & Yes & No \\
\hline rs1011731 & $\begin{array}{l}\text { DNM3 (dynamin 3) - PIGC (phosphatidylinositol } \\
\text { glycan anchor biosynthesis, class C) }\end{array}$ & WHR & Yes & Yes & No \\
\hline rs1294421 & LY86 (lymphocyte antigen 86) & WHR & Yes & Yes & No \\
\hline rs6784615 & NISCH (nischarin) - STABI (stabilin 1) & WHR & Yes & Yes & No \\
\hline rs6861681 & $\begin{array}{l}\text { CPEB4 (cytoplasmic polyadenylation element } \\
\text { binding protein 4) }\end{array}$ & WHR & Yes & Yes & No \\
\hline rs987237 & $\begin{array}{l}\text { TFAP2B (transcription factor activating } \\
\text { enhancer-binding protein } 2 \text { beta) }\end{array}$ & WC & Yes & Yes & No \\
\hline rs7826222 & MSRA (methionine sulfoxide reductase A) & WC & Yes & Yes & No \\
\hline
\end{tabular}

WHR waist-to-hip ratio, WC waist circumference.

men [54]. Undoubtedly, epigenetic regulation of gene expression by environmental and/or hormonal factors contributes significantly to individual variation and sex differences in fat distribution. Animal studies show that exposure to sex steroids early in life alters adipose tissue distribution and function in adulthood [64,65]. In humans, sex differences in epigenetic regulation have been reported in several tissues [66-69] and are feasible to test in adipose tissue [70]. Recent studies showing that acute exercise, overfeeding, and type 2 diabetes can modulate gene expression in skeletal muscle through epigenetic mechanisms [71-73] open the exciting scenario that lifestyle factors can interact with developmental programming to regulate adipose tissue mass and distribution.

\section{Metabolic significance of body fat distribution Body fat distribution is linked to health in both men and women}

Since the seminal work of Jean Vague, it has become clear that sex differences in adiposity and fat distribution are closely associated with whole body metabolism and long-term health $[74,75]$. Thus, although BMI is in itself a strong predictor of total mortality [76], this is far from a simple, universal relationship. Certain individuals retain metabolic health despite being morbidly obese [77], while others develop disease at paradoxically normal adiposity levels [78]. In both sexes, a peripheral body fat distribution clearly dissociates fat mass from risk for metabolic diseases $[79,80]$.

\section{Gluteal-femoral fat distribution is associated with lower metabolic risk}

The clinical significance of body fat distribution is supported by multiple epidemiological studies that confirm the detrimental effect of central body and the protective effect of gluteal-femoral fat on diabetes $[81,82]$, cardiovascular risk and eventually morbidity and mortality [1,76,83-89]. Early clinical studies based on anthropometric measurements also showed very clearly that the protective peripheral fat distribution phenotype (pear shape) is mainly seen in women [90]. However, $40 \%$ of women between the age of 30-79 store fat predominantly in the abdominal area as evident by a waist-to-hip ratio $>0.85$ [91]. These so-called upper body obese women suffer from the same metabolic complications as men [92].

As recently reviewed [93], premenopausal women, compared to age-matched men, have better lipid profiles: 
higher high density lipoprotein (HDL)-cholesterol levels and lower low density lipoprotein (LDL)-cholesterol, very low density lipoprotein (VLDL)-cholesterol and total triglyceride levels. Importantly, this improved lipid profile is seen both in the fasting state and postprandially $[94,95]$ and the sex differences cannot be attributed solely to preferential VAT accumulation in men [96]. Although fasting insulin concentrations are comparable between BMImatched men and women [97], women show improved insulin sensitivity at the level of liver and skeletal muscle (reviewed in [98]). This apparent contradiction between higher total body fat and improved systemic metabolism in women intuitively leads to questions about sex differences in the biology and function of different adipose tissue depots.

\section{Mechanisms linking gluteal-femoral fat to metabolic risk are unclear}

The storage capacity of gluteal-femoral adipose tissues may play a role in determining the level of central adiposity. A recent randomized-controlled trial in nonobese women showed that removal of thigh fat by liposuction is followed by re-accumulation preferentially in the abdominal area, suggesting that effective peripheral fat storage may protect from the expansion of central fat depots [99]. This 'redistribution' of fat would be expected to have an impact on metabolic risk over the long term. However, it is also possible that gluteal-femoral adipose tissue plays an active role in metabolism. Studies in male mice show that transplantation of inguinal SAT as compared to epididymal (which has properties of visceral depots) inside the abdominal cavity leads to less body weight gain and better glucose tolerance $[100,101]$. On the other hand, other laboratories report that transplantation of epididymal fat into the abdominal cavity also improves glucose tolerance [102,103]. Whether SAT of female mice has more potent effects has yet to be reported, and we are currently undertaking these studies.

\section{Sex differences in adipose tissue metabolic function}

The major function of adipose tissue is the appropriate and highly regulated storage and release of energy (Figure 1). Free fatty acids (FFA), either circulating or derived from chylomicrons, VLDL-cholesterol and triglycerides (TG) by the action of lipoprotein lipase (LPL), are taken up by the adipocytes and stored as intracellular TG, three fatty acids esterified to a glycerol backbone. Stored TG can be mobilized as required between meals and in the starved state. Insulin and catecholamines act as the main regulatory signals of the fed and the fasted state respectively. The integrated regulation of TG storage and mobilization together with the endocrine function of adipose tissue are essential for whole body metabolism as reviewed before [104]. Depot differences in abdominal versus gluteofemoral fat have been reviewed in detail $[1,93]$ so here we will emphasize the sex-specific characteristics.

\section{Storage of energy in adipose tissue: subtle differences between sexes}

It would be reasonable to expect that women are more effective in storing fat subcutaneously and men intraabdominally, as that could explain preferential fat deposition. Indeed early in vitro studies suggested that subcutaneous adipocytes/adipose tissue from women show higher LPL activity [105], lipid synthesis [106] and insulin-stimulated glucose uptake $[107,108]$ compared to men. In vivo studies however show that the answer is more complex.

Women store a higher percentage of meal-derived FA in SAT compared to men (38\% vs $24 \%$ ) [109,110], but this is a direct result of their greater SAT mass. When expressed as per gram of adipose tissue lipid, i.e. per unit of fat mass, FA uptake is comparable between sexes in all three SAT depots (abdominal, gluteal and thigh) [109]. On the other hand, the uptake of meal-derived fatty acids by VAT in men exceeds that in women, whether it is calculated as \% of total meal disposal or as absolute values $(\mu \mathrm{mol} / \mathrm{min})$ [111]. Thus, differences in FFA storage after a meal are likely to contribute to VAT expansion in men, but less likely to contribute to SAT expansion in women.

Under certain conditions though, the female tendency to store fat in the peripheral subcutaneous depots becomes more apparent. In response to a hypercaloric, high-fat meal, storage of meal-derived triglyceride-fatty acids per gram of adipose tissue lipid is increased preferentially in the gluteofemoral SAT of women compared to men [112], despite the fact that the adipocytes are larger, i.e. there are fewer adipocytes per gram. Additionally, meal fat storage is more efficient in peripheral vs. abdominal SAT of women with gluteal-femoral obesity; in upper body obese women or obese men there are no such regional differences [113]. These findings appear to be driven by depot differences in LPL activity [111], which is a rate-determining step in the uptake of circulating triglycerides. Further studies are needed to assess the mechanisms for these depot- and sexspecific phenomena, including assessment of regional differences in sex steroid action on LPL [114-116] in men and women of varying fat distribution.

Net fat storage in the adipose tissue after a meal requires inhibition of lipolysis, achieved by increased circulating insulin levels. This mechanism is less effective both in men and in upper body obese women $[117,118]$ compared to women with peripheral fat distribution. Differences in insulin sensitivity (higher in females) are reproduced in vitro in isolated adipocytes of pre- [119], but not post-menopausal women [120] and can also be causally linked to the detrimental postprandial metabolic profile seen in men and upper body obese women. 


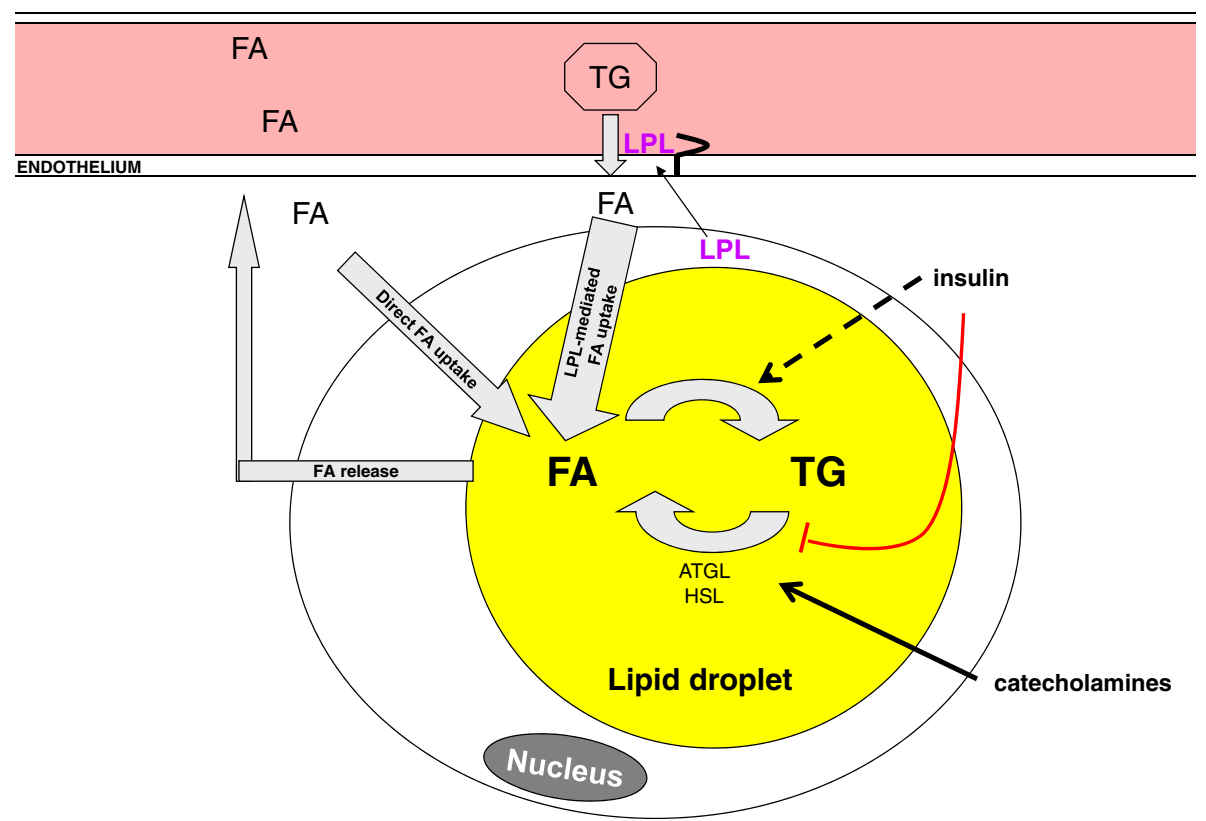

Figure 1 Simplified overview of adipocyte metabolism. After a meal, triglycerides (TG) packaged into chylomicrons are transported to the adipocytes. The enzyme lipoprotein lipase (LPL) made in the adipocyte is secreted to the capillary endothelium were it cleaves TG to fatty acids (FA) which are in turn taken up by the adipocyte and esterified to a backbone of alpha-glycerophosphate (which is mainly derived from glucose). Insulin stimulates this process, mainly by stimulating glucose uptake. Stored TG can be mobilized after hydrolysis by lipases (adipose tissue triglyceride lipase - ATGL and hormone sensitive lipase - HSL). The process of lipolysis is stimulated by catecholamines and inhibited by insulin. Gluteofemoral adipocytes of women are more efficient in storing FA via the direct pathway and also show higher LPL activity. See text for details.

Although it was once believed that LPL-mediated uptake of fatty acids from circulating TG-rich lipoproteins at the fed state is the major or sole mechanism for FA provision to the adipose tissue, the importance of direct uptake of circulating FFA at the postabsorptive state is now realized [121]. This pathway shows clear sexual dimorphism: at the whole body level, women deposit double the percentage of circulating FFA (8.2\% versus $4.0 \%)$ in body fat. Furthermore, lean men are less efficient at depositing circulating FFA into femoral as compared to abdominal adipose tissue, while lean women show no depot difference [121]. In obese subjects direct FFA uptake is enhanced specifically in the femoral tissue of women [121]. The peripheral fat depots of women are also more effective in FFA storage during physical activity (walking) in comparison to both abdominal SAT of women or to any SAT depot of men [122]. Higher direct FFA storage was also noted in the omental adipose tissue of women (a visceral depot), which is opposite to what would be predicted from the lower mass of this depot in women. Therefore, the capacity for direct FFA deposition is likely not the major determinant of visceral adiposity [123].

To summarize, differences in fat deposition between sexes are likely to arise partly due to: a) the preferential postabsorptive direct FFA uptake by SAT in women and b) the enhanced postprandial meal-derived FFA uptake by VAT in men (Figure 2).

\section{Release of energy from adipose tissue: female adipose tissue is more lipolytically active}

To achieve normal fatty acid homeostasis, the FFA flux to or from adipose tissue needs to match whole body energy requirements. FA release in excess of the needs of other tissues leads to elevated circulating FFA levels or flux, which in turn contribute to insulin resistance, ectopic lipid accumulation and lipotoxicity. Thus, it comes as no surprise that total FFA flux correlates closely with whole body energy requirements (resting energy expenditure [124]). Given the higher fat levels in women, one could hypothesize that release of FFA (lipolysis) would be suppressed compared to men. On the contrary, lipolysis relative to resting energy expenditure is significantly higher (by about $40 \%$ ) in women [124]. This is achieved without deleterious consequences partly because women are more dependent on fat oxidation than men in periods of high energy requirements like exercise, when men tend to utilize more carbohydrates [125]. Therefore, the increased lipolysis is a mechanism that matches well the preferential use of FFA in women.

On the other hand, lipolytic rates in women are higher than in men even under resting conditions when FA oxidation is comparable between sexes [125]. This is associated with $\sim 15 \%$ higher levels of circulating FFA levels [126] but not with any detrimental effects on whole body metabolism $[127,128]$. It follows logically that for women 

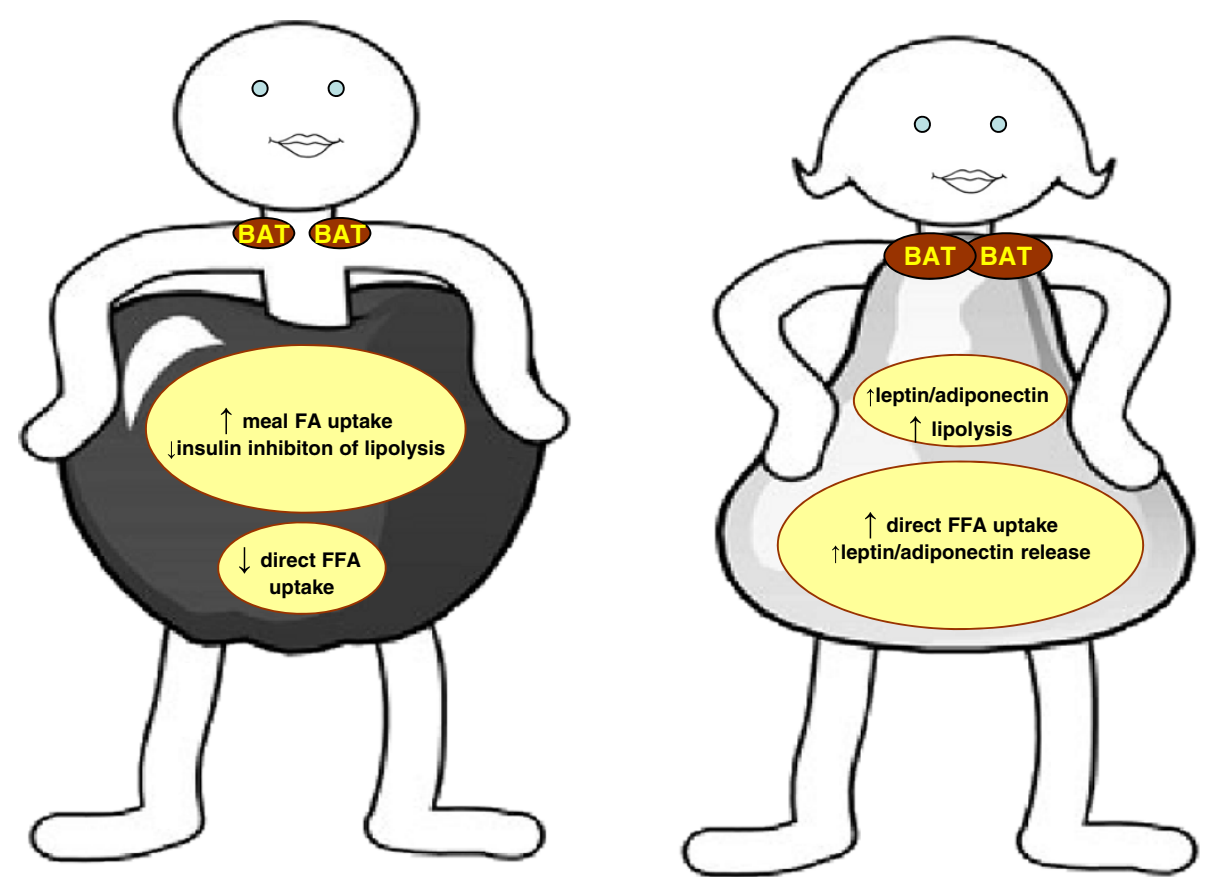

Figure $\mathbf{2}$ Key sex differences in adipose tissue. Compared to men, women are characterized by increased amounts of brown adipose tissue BAT and enlarged peripheral fat depots, whereas intra-abdominal fat depots are preferentially increased in men. Sex differences in the metabolic and endocrine function of these depots are associated with diminished disease risk in women. FFA free fatty acids.

to preserve their insulin sensitivity, they have to be more effective in alternative FFA disposal [124]. Indeed, recent studies demonstrated that women exhibit higher nonoxidative FFA disposal (i.e. esterification and storage as triglycerides) [129] and after an overnight fast, they preferentially partition FFA towards hepatic oxidation to ketone bodies, rather than incorporation into VLDL-TG [130]. FFA can also be shuttled back to adipose tissue through the direct FFA uptake pathway discussed above.

Sex differences in systemic lipolysis appear to arise at the level of the upper-body SAT which is, in both sexes, the main source of circulating FFA $[117,131,132]$. Norepinephrine-stimulated lipolysis in abdominal SAT in women exceeds that seen in men both in vivo and ex vivo [133,134]. Similarly, after exercise, the increase in circulating glycerol is augmented in women compared to men $[125,135]$, as well as the glycerol release specifically by the abdominal SAT (no differences were seen between sexes in the gluteofemoral SAT) [135,136]. Prolonged fasting (up to $72 \mathrm{~h}$ ) leads to exacerbated stimulation of lipolysis in women compared to men, despite comparable rises in catecholamine levels $[137,138]$. The opposite holds true for VAT, where ex vivo and in vivo stimulation of lipolysis is higher in men [134,139,140], but this has more impact on FA flux to the liver via the portal circulation and little impact on systemic FFA flux. Finally in men, ex vivo lipolysis is higher in intra-peritoneal (omental and mesenteric) than retro-peritoneal depots, while the opposite occurs in women, but the in vivo physiological significance of these observations is unclear [139].

To summarize: women, compared to men, show higher rates of mobilization of adipose tissue TG stores, possibly because they are more dependent on FFA as an energy source under conditions of high energy demands like exercise. At the same time they are more efficient in handling FFA and thus retain their insulin sensitivity. Depot differences in lipolysis however cannot explain the peripheral deposition of fat in women compared to men (Figure 2).

\section{Sex differences in the endocrine function of adipose tissue}

Apart from regulating fuel homeostasis, adipose tissue releases a multitude of secretory products, collectively called adipokines. The regulation of adipokine release 
and their individual roles have been reviewed extensively $([141,142]$ among others). The two major adipokines are leptin, a metabolic regulator and feedback signal of body fat to regulate appetite, and adiponectin, an insulinsensitizing and anti-inflammatory hormone. Multiple studies have established that women have higher circulating leptin levels compared to men, even after adjusting for differences in BMI and body fat content $[143,144]$ and this finding is replicated in ex vivo adipose tissue cultures [145]. Interestingly, although sex differences in leptin are augmented during puberty, they are also apparent in children and even in neonates [146-148]. Leptin levels do not decline with menopause suggesting again that the higher leptin relative to body fat in women is not simply due to sex steroids (although postmenopausal women have slightly lower leptin per $\mathrm{kg}$ of fat compared to premenopausal women, they still have higher levels in comparison to men) $[149,150]$. Higher circulating adiponectin concentrations are also seen in women despite their higher adiposity, which is associated in both sexes with lower adiponectin levels [151-153]. These sex differences in adipokine production are of dual significance. They suggest inherent differences in adipocyte function between sexes or differential regulation by hormones, e.g. suppressive effects of androgens on leptin and adiponectin production $[148,152]$. More importantly, they may be also directly and causally related to the differences in whole body insulin sensitivity and metabolism seen between sexes.

\section{Sex steroids influence depot-specific adipose tissue metabolism and endocrine function}

It is evident from the changes taking place during puberty and menopause, in women with polycystic ovary syndrome and in transgendered individuals that sex hormones have multiple effects of adipose tissue. The exact mechanisms involved remain largely obscure. Human adipocytes, as well as preadipocytes, express sex steroid receptors $[154,155]$. Both estrogens and androgens blunt lipolytic responses to catecholamines, an effect that is modulated at least partly via changes in adrenergic receptors expression [156,157], and also suppress LPL expression and activity [115,158]. Androgens have also been shown to increase glucose uptake [159]. Sex steroids have contradictory effects on leptin secretion - estrogens induce it and androgens inhibit it - in a sex specific manner, i.e. more so in adipocytes derived from women than from men $[160,161]$. It is also possible that sex steroids affect adipose tissue biology primarily via effects on the central nervous system, rather than via direct effects on the adipocytes. For example, in animal models, estrogen effects on steroidogenic factor-1 neurons of the ventromedial hypothalamic nucleus enhance brown adipose tissue thermogenesis and specifically limit visceral adipose tissue accumulation [162].

\section{Sex steroids may regulate adipose tissue growth in a depot specific manner}

Adipose tissue expands through enlargement of existing adipocytes and recruitment of progenitors. Sex differences in fat distribution involve both cell size and number: gluteo-femoral adipocytes of women are larger than in men, whereas abdominal adipocytes are comparable between sexes, and visceral adipocytes of women are smaller [105]. Nevertheless, the expansion of subcutaneous depots in obese women compared to men is mainly due to higher cell numbers [90,105]. More recently and with more exact imaging techniques, it was again shown that femoral fat accumulation in women is associated with increased adipocyte number (hyperplasia) whereas in men with increased adipocyte size (hypertrophy). Fat accumulation in the abdominal area is associated with hypertrophy in both sexes, but women start with more adipocytes even at the lean state and can therefore accommodate larger fat mass [163].

Although extensive studies document depot differences in the capacity of different depots of rodents to expand through hyperplasia [164,165], remarkably little is known about humans. Limited data suggest that the SAT of women, and particularly the femoral depot, contains a higher percentage of early differentiated adipocytes compared to men. Interestingly, in vitro proliferation and differentiation of preadipocytes isolated from the same individuals were comparable between sexes, leading these authors to suggest that the local microenvironment rather than inherent cellular differences promotes adipogenesis in women [166].

In vitro, estrogens stimulate proliferation of human preadipocytes $[167,168]$, whereas androgens inhibit differentiation without affecting proliferation [158,169]. However, whether specific depots are differentially sensitive to sex steroid effects and potential sex-differences in response to these hormones are yet to be systemically investigated.

\section{The systems biology of sex differences in adipose tissue}

A comprehensive analysis of the gene networks that differ in 'visceral' adipose tissues (unspecified) of male and female mice clearly shows that gene networks identified in each sex affect different pathways and have different associations with metabolic and obesity traits (4). Recent studies in humans indicate the existence of sex biased mRNA and miRNA expression in abdominal and gluteal adipose tissues that will undoubtedly yield new mechanistic insights $[170,171]$.

\section{Conclusions}

Sex differences in the fat phenotypes are probably determined by a complex interplay of genetic, epigenetic, and hormonal factors. Elegant in vivo studies of depot- and sex- 
specific differences in adipose tissue metabolism showed that the primary suspects (lipid uptake and mobilization) are not the main mediators and at the same time pointed to new pathways (direct FFA uptake) for further investigation. We still do not know if sex differences in the function of female adipocytes are mainly derived from genetic, cell autonomous properties related to sex chromosomes or from critical early imprinting events by sex steroids. The direct effects of sex hormones on adipocyte function and the importance of the microenvironment of specific adipose depots on growth remain poorly understood. Much more work will be required to integrate all the data arising from studies of global gene and miRNA expression, as well as of epigenetic changes, and to understand why females can accumulate more adipose tissue than men without deleterious metabolic consequences, and how gluteal-femoral adipose tissue in particular lessens metabolic risk.

\section{Competing interests}

The authors have no competing interests to disclose.

\section{Acknowledgements}

We thank Colleen Russell, Ph.D. for her careful reading of this manuscript and suggestions

The authors are supported by NIH (R24DK087669, P30DK46200,

P30DK072476, DK082574 and 1RC2ES01871), the Society for Women's Health Research ISIS Network on Metabolism, United States Department of Agriculture's Agricultural Research Service (58-1950-7-707), and the Evans Center for Interdisciplinary Biomedical Research, Department of Medicine, Boston University School of Medicine.

\section{Author details}

'Department of Medicine, Section of Endocrinology, Diabetes \& Nutrition, Boston University School of Medicine, Boston, MA, USA. ${ }^{2}$ Diabetes and Obesity Research Center, Sanford/Burnham Medical Research Institute at Lake Nona, Orlando, FL and Translational Research Institute for Metabolism and Diabetes, Florida Hospital, Sanford/Burnham Medical Research Institute at Lake Nona, Orlando, FL, USA. ${ }^{3}$ Human Nutrition Research Center on Aging, Tufts University, Boston, MA, USA. ${ }^{4}$ Division of Endocrinology, Diabetes, and Nutrition, Department of Medicine, Boston University, School of Medicine, 650 Albany St, EBRC-810, Boston, MA 02118, USA.

\section{Authors' contributions}

KK drafted and SKF edited the manuscript. SRS and ASG reviewed the manuscript and made suggestions. All authors read and approved the final manuscript.

Received: 15 February 2012 Accepted: 31 May 2012

Published: 31 May 2012

\section{References}

1. Manolopoulos KN, Karpe F, Frayn KN: Gluteofemoral body fat as a determinant of metabolic health. Int J Obes 2010, 34:949-959.

2. Pi-Sunyer FX: The epidemiology of central fat distribution in relation to disease. Nutr Rev 2004, 62:S120-S126

3. Gesta S, Blüher M, Yamamoto Y, Norris AW, Berndt J, Kralisch S, Boucher J, Lewis $C$, Kahn CR: Evidence for a role of developmental genes in the origin of obesity and body fat distribution. Proc Natl Acad Sci U S A 2006, 103:6676-6681.

4. van Nas A, Guhathakurta D, Wang SS, Yehya N, Horvath S, Zhang B, IngramDrake L, Chaudhuri G, Schadt EE, Drake TA, Arnold AP, Lusis AJ: Elucidating the role of gonadal hormones in sexually dimorphic gene coexpression networks. Endocrinology 2009, 150:1235-1249.
5. Grove KL, Fried SK, Greenberg AS, Xiao XQ, Clegg DJ: A microarray analysis of sexual dimorphism of adipose tissues in high-fat-diet-induced obese mice. Int J Obes 2010, 34:989-1000.

6. Shi H, Seeley RJ, Clegg DJ: Sexual differences in the control of energy homeostasis. Front Neuroendocrinol 2009, 30:396-404.

7. Brown LM, Gent L, Davis K, Clegg DJ: Metabolic impact of sex hormones on obesity. Brain Res 2010, 1350:77-85.

8. Cinti S: The adipose organ: morphological perspectives of adipose tissues. Proc Nutr Soc 2001, 60:319-328.

9. Seidell JC, Oosterlee A, Deurenberg P, Hautvast JG, Ruijs JH: Abdominal fat depots measured with computed tomography: effects of degree of obesity, sex, and age. Eur J Clin Nutr 1988, 42:805-815.

10. Haupt A, Thamer C, Heni M, Machicao F, Machann J, Schick F, Stefan N, Fritsche A, Häring HU, Staiger H: Novel obesity risk loci do not determine distribution of body fat depots: a whole-body MRI/MRS study. Obesity (Silver Spring) 2010, 18:1212-1217.

11. Ludescher B, Najib A, Baar S, Machann J, Thamer C, Schick F, Buchkremer G, Claussen CD, Eschweiler GW: Gender specific correlations of adrenal gland size and body fat distribution: a whole body MRI study. Horm Metab Res 2007, 39:515-518.

12. Thomas EL, Saeed N, Hajnal JV, Brynes A, Goldstone AP, Frost G, Bell JD: Magnetic resonance imaging of total body fat. J App/ Physio/ 1998, 85:1778-1785.

13. Abate N, Garg A, Peshock RM, Stray-Gundersen J, Grundy SM: Relationships of generalized and regional adiposity to insulin sensitivity in men. J Clin Invest 1995, 96:88-98.

14. Cypess AM, Lehman S, Williams G, Tal I, Rodman D, Goldfine AB, Kuo FC, Palmer EL, Tseng YH, Doria A, Kolodny GM, Kahn CR: Identification and importance of brown adipose tissue in adult humans. N Engl J Med 2009, 360:1509-1517.

15. Lee P, Greenfield JR, Ho KK, Fulham MJ: A critical appraisal of the prevalence and metabolic significance of brown adipose tissue in adult humans. Am J Physiol Endocrinol Metab 2010, 299:E601-E606.

16. Ouellet $\mathrm{V}$, Labbé SM, Blondin DP, Phoenix S, Guérin B, Haman F, Turcotte EE, Richard D, Carpentier AC: Brown adipose tissue oxidative metabolism contributes to energy expenditure during acute cold exposure in humans. J Clin Invest 2012, 122:545-552.

17. Ravussin E, Galgani JE: The implication of brown adipose tissue for humans. Annu Rev Nutr 2011, 31:33-47.

18. Cannon B, Nedergaard J: Yes, even human brown fat is on fire! $J$ Clin Invest 2012, 122:486-489.

19. Womersley J, Durnin JVGA: A comparison of the skinfold method with extent of overweight and various weight-height relationships in the assessment of obesity. Br J Nutr 1977, 38:271-284.

20. Jackson AS, Stanforth PR, Gagnon J, Rankinen T, Leon AS, Rao DC, Skinner JS, Bouchard C, Wilmore JH: The effect of sex, age and race on estimating percentage body fat from body mass index: The Heritage Family Study. Int J Obes Relat Metab Disord 2002, 26:789-796.

21. Gallagher D, Visser M, Sepúlveda D, Pierson RN, Harris T, Heymsfield SB: How useful is body mass index for comparison of body fatness across age, sex, and ethnic groups? Am J Epidemiol 1996, 143:228-239.

22. Camhi SM, Bray GA, Bouchard C, Greenway FL, Johnson WD, Newton RL, Ravussin E, Ryan DH, Smith SR, Katzmarzyk PT: The relationship of waist circumference and BMI to visceral, subcutaneous, and total body fat: sex and race differences. Obesity (Silver Spring) 2011, 19:402-408.

23. Schreiner PJ, Terry JG, Evans GW, Hinson WH, Crouse JR 3rd, Heiss G: Sex-specific associations of magnetic resonance imaging-derived intra-abdominal and subcutaneous fat areas with conventional anthropometric indices. The Atherosclerosis Risk in Communities Study. Am J Epidemiol 1996, 144:335-345.

24. Després JP, Couillard C, Gagnon J, Bergeron J, Leon AS, Rao DC, Skinner JS, Wilmore JH, Bouchard C: Race, visceral adipose tissue, plasma lipids, and lipoprotein lipase activity in men and women: the Health, Risk Factors, Exercise Training, and Genetics (HERITAGE) family study. Arterioscler Thromb Vasc Biol 2000, 20:1932-1938.

25. Demerath EW, Sun SS, Rogers N, Lee M, Reed D, Choh AC, Couch W, Czerwinski SA, Chumlea WC, Siervogel RM, Towne B: Anatomical patterning of visceral adipose tissue: race, sex, and age variation. Obesity (Silver Spring) 2007, 15:2984-2993.

26. Goodpaster BH, Krishnaswami S, Harris TB, Katsiaras A, Kritchevsky SB, Simonsick EM, Nevitt M, Holvoet P, Newman AB: Obesity, regional body fat distribution, and the metabolic syndrome in older men and women. Arch Intern Med 2005, 165:777-783. 
27. Yim JE, Heshka S, Albu JB, Heymsfield S, Gallagher D: Femoral-gluteal subcutaneous and intermuscular adipose tissues have independent and opposing relationships with CVD risk. J Appl Physiol 2008, 104:700-707.

28. Smith SR, Lovejoy JC, Greenway F, Ryan D, de Jonge L, de la Bretonne J, Volafova J, Bray GA: Contributions of total body fat, abdominal subcutaneous adipose tissue compartments, and visceral adipose tissue to the metabolic complications of obesity. Metabolism 2001, 50:425-435.

29. Goodman-Gruen D, Barrett-Connor E: Sex differences in measures of body fat and body fat distribution in the elderly. Am J Epidemiol 1996, 143:898-906.

30. Lear SA, Humphries KH, Kohli S, Chockalingam A, Frohlich JJ, Birmingham CL: Visceral adipose tissue accumulation differs according to ethnic background: results of the Multicultural Community Health Assessment Trial (M-CHAT). Am J Clin Nutr 2007, 86:353-359.

31. Maynard LM, Wisemandle W, Roche AF, Chumlea WC, Guo SS, Siervogel RM: Childhood body composition in relation to body mass index. Pediatrics 2001, 107:344-330.

32. Hattori K, Tahara Y, Moji K, Aoyagi K, Furusawa T: Chart analysis of body composition change among pre- and postadolescent Japanese subjects assessed by underwater weighing method. Int I Obes Relat Metab Disord 2004, 28:520-524.

33. Wells JC: Sexual dimorphism of body composition. Best Pract Res Clin Endocrinol Metab 2007, 21:415-430

34. Ley CJ, Lees B, Stevenson JC: Sex- and menopause- associated changes in body-fat distribution. Am J Clin Nutr 1992, 55:950-954

35. Svendsen OL, Hassager C, Christiansen C: Age- and menopause-associated variations in body composition and fat distribution in healthy women as measured by dual-energy X-ray absorptiometry. Metabolism 1995, 44:369-373.

36. Toth MJ, Tchernof A, Sites CK, Poehlman ET: Effect of menopausal status on body composition and abdominal fat distribution. Int J Obes Relat Metab Disord 2000, 24:226-231

37. Lovejoy JC, Champagne CM, de Jonge L, Xie H, Smith SR: Increased visceral fat and decreased energy expenditure during the menopausal transition. Int J Obes 2008, 32:949-958.

38. Allan CA, Strauss BJ, Burger HG, Forbes EA, McLachlan Rl: Testosterone therapy prevents gain in visceral adipose tissue and loss of skeletal muscle in nonobese aging men. J Clin Endocrinol Metab 2008, 93:139-146.

39. Stevens J, Katz EG, Huxley RR: Associations between gender, age and waist circumference. Eur J Clin Nutr 2010, 64:6-15.

40. Puder JJ, Varga S, Kraenzlin M, De Geyter C, Keller U, Müller B: Central fat excess in polycystic ovary syndrome: relation to low-grade inflammation and insulin resistance. J Clin Endocrinol Metab 2005, 90:6014-6021.

41. Carmina E, Bucchieri S, Esposito A, Del Puente A, Mansueto P, Orio F, Di Fede G, Rini G: Abdominal fat quantity and distribution in women with polycystic ovary syndrome and extent of its relation to insulin resistance. J Clin Endocrinol Metab 2007, 92:2500-2505.

42. Barber TM, Golding SJ, Alvey C, Wass JA, Karpe F, Franks S, McCarthy MI: Global adiposity rather than abnormal regional fat distribution characterizes women with polycystic ovary syndrome. J Clin Endocrinol Metab 2008, 93:999-1004.

43. Elbers JM, Asscheman H, Seidell JC, Gooren LJ: Effects of sex steroid hormones on regional fat depots as assessed by magnetic resonance imaging in transsexuals. Am J Physiol 1999, 276:E317-E325.

44. Stunkard AJ, Harris JR, Pedersen NL, McClearn GE: The body-mass index of twins who have been reared apart. N Engl J Med 1990, 322:1483-1487.

45. Schousboe K, Willemsen G, Kyvik KO, Mortensen J, Boomsma DI, Cornes BK, Davis CJ, Fagnani C, Hjelmborg J, Kaprio J, De Lange M, Luciano M, Martin NG, Pedersen N, Pietiläinen KH, Rissanen A, Saarni S, Sørensen TI, Van Baal GC, Harris JR: Sex differences in heritability of BMI: a comparative study of results from twin studies in eight countries. Twin Res 2003, 6:409-421.

46. Dempfle A, Hinney A, Heinzel-Gutenbrunner M, Raab M, Geller F,

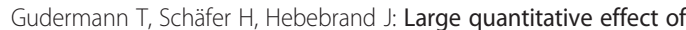
melanocortin-4 receptor gene mutations on body mass index. J Med Genet 2004, 41:795-800.

47. Stone S, Abkevich V, Russell DL, Riley R, Timms K, Tran T, Trem D, Frank D, Jammulapati S, Neff CD, lliev D, Gress R, He G, Frech GC, Adams TD, Skolnick MH, Lanchbury JS, Gutin A, Hunt SC, Shattuck D: TBC1D1 is a candidate for a severe obesity gene and evidence for a gene/gene interaction in obesity predisposition. Hum Mol Genet 2006, 15:2709-2720.
48. Meyre D, Farge M, Lecoeur C, Proenca C, Durand E, Allegaert F, Tichet J, Marre M, Balkau B, Weill J, Delplanque J, Froguel P: R125W coding variant in TBC1D1 confers risk for familial obesity and contributes to linkage on chromosome 4p14 in the French population. Hum Mol Genet 2008, 17:1798-1802

49. Araújo-Vilar D, Loidi L, Domínguez F, Cabezas-Cerrato J: Phenotypic gender differences in subjects with familial partial lipodystrophy (Dunnigan variety) due to a nuclear lamin A/C R482W mutation. Horm Metab Res 2003, 35:29-35.

50. Okura T, Koda M, Ando F, Niino N, Ohta S, Shimokata H: Association of polymorphisms in the estrogen receptor alpha gene with body fat distribution. Int J Obes Relat Metab Disord 2003, 27:1020-1027.

51. Gallagher CJ, Langefeld CD, Gordon CJ, Campbell JK, Mychaleckyj JC, Bryer-Ash M, Rich SS, Bowden DW, Sale MM: Association of the estrogen receptor-alpha gene with the metabolic syndrome and its component traits in African-American families: the Insulin Resistance Atherosclerosis Family Study. Diabetes 2007, 56:2135-2141.

52. Nilsson M, Dahlman I, Jiao H, Gustafsson JA, Arner P, Dahlman-Wright K: Impact of estrogen receptor gene polymorphisms and mRNA levels on obesity and lipolysis-a cohort study. BMC Med Genet 2007, 8:73.

53. Speliotes EK, Willer CJ, Berndt SI, Monda KL, Thorleifsson G, Jackson AU, Allen HL, Lindgren CM, Luan J, Mägi R, Randall JC, Vedantam S, Winkler TW, Qi L, Workalemahu T, Heid IM, Steinthorsdottir V, Stringham HM, Weedon MN, Wheeler E, Wood AR, Ferreira T, Weyant RJ, Segrè AV, Estrada K, Liang L, Nemesh J, Park JH, Gustafsson S, Kilpeläinen TO, et al: Association analyses of 249,796 individuals reveal 18 new loci associated with body mass index. Nat Genet 2010, 42:937-948.

54. Heid IM, Jackson AU, Randall JC, Winkler TW, Qi L, Steinthorsdottir V Thorleifsson G, Zillikens MC, Speliotes EK, Mägi R, Workalemahu T, White CC, Bouatia-Naji N, Harris TB, Berndt SI, Ingelsson E, Willer CJ, Weedon MN, Luan J, Vedantam S, Esko T, Kilpeläinen TO, Kutalik Z, Li S, Monda KL, Dixon AL, Holmes CC, Kaplan LM, Liang L, Min JL, et al: Meta-analysis identifies 13 new loci associated with waist-hip ratio and reveals sexual dimorphism in the genetic basis of fat distribution. Nat Genet 2010, 42:949-960.

55. Lindgren CM, Heid IM, Randall JC, Lamina C, Steinthorsdottir V, Qi L, Speliotes EK, Thorleifsson G, Willer CJ, Herrera BM, Jackson AU, Lim N, Scheet P, Soranzo N, Amin N, Aulchenko YS, Chambers JC, Drong A, Luan J, Lyon HN, Rivadeneira F, Sanna S, Timpson NJ, Zillikens MC, Zhao JH, Almgren P, Bandinelli S, Bennett AJ, Bergman RN, Bonnycastle LL, et al: Genome-wide association scan meta-analysis identifies three Loci influencing adiposity and fat distribution. PLOS Genet 2009, 5:e1000508.

56. Cao Y: Angiogenesis modulates adipogenesis and obesity. J Clin Invest 2007, 117:2362-2368.

57. Cariou B, Capitaine N, Le Marcis V, Vega N, Béréziat V, Kergoat M, Laville M, Girard J, Vidal H, Burnol AF: Increased adipose tissue expression of Grb14 in several models of insulin resistance. FASEB J 2004, 18:965-967.

58. Cooney GJ, Lyons RJ, Crew AJ, Jensen TE, Molero JC, Mitchell CJ, Biden TJ, Ormandy CJ, James DE, Daly RJ: Improved glucose homeostasis and enhanced insulin signalling in Grb14-deficient mice. EMBO J 2004, 23:582-593.

59. Ikeda K, Maegawa H, Ugi S, Tao Y, Nishio Y, Tsukada S, Maeda S, Kashiwagi A: Transcription factor activating enhancer-binding protein-2beta. A negative regulator of adiponectin gene expression. J Biol Chem 2006, 281:31245-31253.

60. Tao Y, Maegawa H, Ugi S, Ikeda K, Nagai Y, Egawa K, Nakamura T, Tsukada S, Nishio Y, Maeda S, Kashiwagi A: The transcription factor AP-2beta causes cell enlargement and insulin resistance in 3 T3-L1 adipocytes. Endocrinology 2006, 147:1685-1696.

61. Gesta S, Bezy O, Mori MA, Macotela Y, Lee KY, Kahn CR: Mesodermal developmental gene Tbx15 impairs adipocyte differentiation and mitochondrial respiration. Proc Natl Acad Sci U S A 2011, 108:2771-2776.

62. Kim KA, Wagle M, Tran K, Zhan X, Dixon MA, Liu S, Gros D, Korver W, Yonkovich S, Tomasevic N, Binnerts M, Abo A: R-Spondin family members regulate the Wnt pathway by a common mechanism. Mol Biol Cell 2008, 19:2588-2596.

63. Mao B, Wu W, Davidson G, Marhold J, Li M, Mechler BM, Delius H, Hoppe D, Stannek P, Walter C, Glinka A, Niehrs C: Kremen proteins are Dickkopf receptors that regulate Wnt/beta-catenin signalling. Nature 2002, 417:664-667.

64. Alexanderson C, Eriksson E, Stener-Victorin E, Lystig T, Gabrielsson B, Lönn $M$, Holmäng $A$ : Postnatal testosterone exposure results in insulin 
resistance, enlarged mesenteric adipocytes, and an atherogenic lipid profile in adult female rats: comparisons with estradiol and dihydrotestosterone. Endocrinology 2007, 148:5369-5376.

65. Zhang FF, Cardarelli R, Carroll J, Fulda KG, Kaur M, Gonzalez K, Vishwanatha JK, Santella RM, Morabia A: Significant differences in global genomic DNA methylation by gender and race/ethnicity in peripheral blood. Epigenetics 2011, 6:623-629

66. Waxman DJ, O'Connor C: Growth hormone regulation of sex-dependent liver gene expression. Mol Endocrinol 2006, 20:2613-2629.

67. Nilsson C, Niklasson M, Eriksson E, Björntorp P, Holmäng A: Imprinting of female offspring with testosterone results in insulin resistance and changes in body fat distribution at adult age in rats. J Clin Invest 1998, 101:74-78.

68. McCarthy MM, Auger AP, Bale TL, De Vries GJ, Dunn GA, Forger NG, Murray EK, Nugent BM, Schwarz JM, Wilson ME: The epigenetics of sex differences in the brain. J Neurosci 2009, 29:12815-12823.

69. Arnold AP, Lusis AJ: Understanding the Sexome: Measuring and Reporting Sex Differences in Gene Systems. Endocrinology 2012, [Epub ahead of print].

70. Pinnick KE, Karpe F: DNA methylation of genes in adipose tissue. Proc Nutr Soc 2011, 70:57-63.

71. Barrès R, Yan J, Egan B, Treebak JT, Rasmussen M, Fritz T, Caidahl K, Krook A, O'Gorman DJ, Zierath JR: Acute exercise remodels promoter methylation in human skeletal muscle. Cell Metab 2012, 15:405-411

72. Barrès R, Osler ME, Yan J, Rune A, Fritz T, Caidahl K, Krook A, Zierath JR: Non-CpG methylation of the PGC-1alpha promoter through DNMT3B controls mitochondrial density. Cell Metab 2009, 10:189_ 198.

73. Brøns C, Jacobsen $S$, Nilsson $E$, Rönn $T$, Jensen $C B$, Storgaard $H$, Poulsen P, Groop L, Ling C, Astrup A, Vaag A: Deoxyribonucleic acid methylation and gene expression of PPARGC1A in human muscle is influenced by high-fat overfeeding in a birth-weight-dependent manner. J Clin Endocrinol Metab 2010, 95:3048-3056.

74. Vague J: La différentiation sexuelle. Facteur determinant des formes de l'obesité. Press Med 1947, 30:339-340.

75. Vague J: The degree of masculine differentiation of obesity. A factor determining predisposition to diabetes, atherosclerosis, gout and uric calculus disease. Am J Clin Nutr 1956, 4:20-34

76. Whitlock G, Lewington S, Sherliker P, Clarke R, Emberson J, Halsey J, Qizilbash N, Collins R, Peto R, Prospective Studies Collaboration: Body-mass index and cause-specific mortality in 900000 adults: collaborative analyses of 57 prospective studies. Lancet 2009, 373:1083-1096.

77. Blüher M: The distinction of metabolically 'healthy' from 'unhealthy' obese individuals. Curr Opin Lipidol 2010, 21:38-43.

78. Beck E, Esser N, Paquot N, Scheen AJ: Metabolically obese normalweight individuals and metabolically healthy, but obese, subjects. Rev Med Suisse 2009, 5:1644-1646-1648-1649.

79. Snijder MB, Dekker JM, Visser M, Bouter LM, Stehouwer CD, Kostense PJ, Yudkin JS, Heine RJ, Nijpels G, Seidell JC: Associations of hip and thigh circumferences independent of waist circumference with the incidence of type 2 diabetes: the Hoorn Study. Am J Clin Nutr 2003, 77:1192-1197.

80. Snijder MB, Visser M, Dekker JM, Goodpaster BH, Harris TB, Kritchevsky SB, De Rekeneire N, Kanaya AM, Newman AB, Tylavsky FA, Seidell JC: Health $A B C$ Study: Low subcutaneous thigh fat is a risk factor for unfavourable glucose and lipid levels, independently of high abdominal fat. The Health ABC Study. Diabetologia 2005, 48:301308.

81. Chan JM, Rimm EB, Colditz GA, Stampfer MJ, Willett WC: Obesity, fat distribution, and weight gain as risk factors for clinical diabetes in men. Diabetes Care 1994, 17:961-969.

82. Carey VJ, Walters EE, Colditz GA, Solomon CG, Willett WC, Rosner BA, Speizer FE, Manson JE: Body fat distribution and risk of non-insulindependent diabetes mellitus in women. The Nurses' Health Study. Am J Epidemiol 1997, 145:614-619.

83. Lapidus L, Bengtsson C, Larsson B, Pennert K, Rybo E, Sjöström L: Distribution of adipose tissue and risk of cardiovascular disease and death: a 12 year follow up of participants in the population study of women in Gothenburg, Sweden. Br Med J 1984, 289:1257-1261.
84. Folsom AR, Kaye SA, Sellers TA, Hong CP, Cerhan JR, Potter JD, Prineas RJ: Body fat distribution and 5-year risk of death in older women. JAMA 1993, 269:483-487.

85. Seidell JC, Pérusse L, Després JP, Bouchard C: Waist and hip circumferences have independent and opposite effects on cardiovascular disease risk factors: the Quebec Family Study. Am J Clin Nutr 2001, 74:315-321.

86. Okosun IS, Liao Y, Rotimi CN, Prewitt TE, Cooper RS: Abdominal adiposity and clustering of multiple metabolic syndrome in White, Black and Hispanic americans. Ann Epidemiol 2000, 10:263-270.

87. Canoy D, Boekholdt SM, Wareham N, Luben R, Welch A, Bingham S, Buchan I, Day N, Khaw KT: Body fat distribution and risk of coronary heart disease in men and women in the European Prospective Investigation Into Cancer and Nutrition in Norfolk cohort: a population-based prospective study. Circulation 2007, 116:2933-2943

88. Pischon T, Boeing $H$, Hoffmann K, Bergmann M, Schulze MB, Overvad K, van der Schouw YT, Spencer E, Moons KG, Tjønneland A, Halkjaer J, Jensen MK, Stegger J, Clavel-Chapelon F, Boutron-Ruault MC, Chajes V, Linseisen J, Kaaks R, Trichopoulou A, Trichopoulos D, Bamia C, Sieri S, Palli D, Tumino R, Vineis P, Panico S, Peeters PH, May AM, Buenode-Mesquita $H B$, van Duijnhoven FJ, et al: General and abdominal adiposity and risk of death in Europe. N Engl J Med 2008, 359:21052120

89. Després JP: Cardiovascular disease under the influence of excess visceral fat. Crit Pathw Cardiol 2007, 6:51-59.

90. Krotkiewski M, Björntorp P, Sjöström L, Smith U: Impact of obesity on metabolism in men and women. Importance of regional adipose tissue distribution. J Clin Invest 1983, 72:1150-1162.

91. Meigs JB, Wilson PW, Nathan DM, D'Agostino RB Sr, Williams K, Haffner SM: Prevalence and characteristics of the metabolic syndrome in the San Antonio Heart and Framingham Offspring Studies. Diabetes 2003, 52:2160-2167.

92. Jensen MD: Role of body fat distribution and the metabolic complications of obesity. J Clin Endocrinol Metab 2008, 93(11 Suppl 1):S57-S63.

93. Wang X, Magkos F, Mittendorfer B: Sex differences in lipid and lipoprotein metabolism: it's not just about sex hormones. J Clin Endocrinol Metab 2011, 96:885-893.

94. Cohn JS, McNamara JR, Cohn SD, Ordovas JM, Schaefer EJ: Postprandial plasma lipoprotein changes in human subjects of different ages. J Lipid Res 1988, 29:469-479.

95. Couillard C, Bergeron N, Prud'homme D, Bergeron J, Tremblay A, Bouchard $C$, Mauriège $P$, Després JP: Gender difference in postprandial lipemia: importance of visceral adipose tissue accumulation. Arterioscler Thromb Vasc Biol 1999, 19:2448-2455.

96. Lemieux I, Pascot A, Lamarche B, Prud'homme D, Nadeau A, Bergeron J, Després JP: Is the gender difference in LDL size explained by the metabolic complications of visceral obesity? Eur J Clin Invest 2002, 32:909917

97. Foster KJ, Alberti KG, Hinks L, Lloyd B, Postle A, Smythe P, Turnell DC, Walton R: Blood intermediary metabolite and insulin concentrations after an overnight fast: reference ranges for adults, and interrelations. Clin Chem 1978, 24:1568-1572

98. Magkos F, Wang X, Mittendorfer B: Metabolic actions of insulin in men and women. Nutrition 2010, 26:686-693.

99. Hernandez TL, Kittelson JM, Law CK, Ketch LL, Stob NR, Lindstrom RC, Scherzinger A, Stamm ER, Eckel RH: Fat redistribution following suction lipectomy: defense of body fat and patterns of restoration. Obesity (Silver Spring) 2011, 19:1388-1395.

100. Tran TT, Kahn CR: Transplantation of adipose tissue and stem cells: role in metabolism and disease. Nat Rev Endocrinol 2010, 6:195-213.

101. Tran TT, Yamamoto Y, Gesta S, Kahn CR: Beneficial effects of subcutaneous fat transplantation on metabolism. Cell Metab 2008, 7:410-420.

102. Foster MT, Shi H, Softic S, Kohli R, Seeley RJ, Woods SC: Transplantation of non-visceral fat to the visceral cavity improves glucose tolerance in mice: investigation of hepatic lipids and insulin sensitivity. Diabetologia 2011, 54:2890-2899.

103. Konrad D, Rudich A, Schoenle EJ: Improved glucose tolerance in mice receiving intraperitoneal transplantation of normal fat tissue. Diabetologia 2007, 50:833-839.

104. Frayn KN, Karpe F, Fielding BA, Macdonald IA, Coppack SW: Integrative physiology of human adipose tissue. Int J Obes Relat Metab Disord 2003, 27:875-888. 
105. Fried SK, Kral JG: Sex differences in regional distribution of fat cell size and lipoprotein lipase activity in morbidly obese patients. Int J Obes 1987, 11:129-140.

106. Edens NK, Fried SK, Kral JG, Hirsch J, Leibel RL: In vitro lipid synthesis in human adipose tissue from three abdominal sites. Am J Physiol 1993, 265: E374-E379.

107. Pedersen $\mathrm{O}$, Hjøllund $\mathrm{E}$, Lindskov $\mathrm{HO}$ : Insulin binding and action on fat cells from young healthy females and males. Am J Physiol 1982, 243:E158-E167.

108. Foley JE, Kashiwagi A, Chang H, Huecksteadt TP, Lillioja S, Verso MA, Reaven $\mathrm{G}$ : Sex difference in insulin-stimulated glucose transport in rat and human adipocytes. Am J Physiol 1984, 246:E211-E215.

109. Romanski SA, Nelson RM, Jensen MD: Meal fatty acid uptake in adipose tissue: gender effects in nonobese humans. Am J Physiol Endocrinol Metab 2000, 279:E455-E462.

110. Uranga AP, Levine J, Jensen M: Isotope tracer measures of meal fatty acid metabolism: reproducibility and effects of the menstrual cycle. Am J Physiol Endocrinol Metab 2005, 288:E547-E555.

111. Nguyen TT, Hernández Mijares A, Johnson CM, Jensen MD: Postprandial leg and splanchnic fatty acid metabolism in nonobese men and women. Am J Physiol 1996, 271:E965-E972.

112. Votruba SB, Jensen MD: Sex-specific differences in leg fat uptake are revealed with a high-fat meal. Am J Physiol Endocrinol Metab 2006, 291 E1115-E1123.

113. Santosa S, Hensrud DD, Votruba SB, Jensen MD: The influence of sex and obesity phenotype on meal fatty acid metabolism before and after weight loss. Am J Clin Nutr 2008, 88:1134-1141.

114. Rebuffé-Scrive $M$, Mårin P, Björntorp P: Effect of testosterone on abdominal adipose tissue in men. Int J Obes 1991, 15:791-795.

115. Price TM, O'Brien SN, Welter BH, George R, Anandjiwala J, Kilgore M: Estrogen regulation of adipose tissue lipoprotein lipase-possible mechanism of body fat distribution. Am J Obstet Gynecol 1998, 178:101-107.

116. Homma H, Kurachi H, Nishio Y, Takeda T, Yamamoto T, Adachi K, Morishige K, Ohmichi M, Matsuzawa Y, Murata Y: Estrogen suppresses transcription of lipoprotein lipase gene. Existence of a unique estrogen response element on the lipoprotein lipase promoter. J Biol Chem 2000, 275:11404-11411.

117. Jensen MD: Gender differences in regional fatty acid metabolism before and after meal ingestion. J Clin Invest 1995, 96:2297-2303.

118. Guo Z, Hensrud DD, Johnson CM, Jensen MD: Regional postprandial fatty acid metabolism in different obesity phenotypes. Diabetes 1999, 48:1586-1592.

119. Johnson JA, Fried SK, Pi-Sunyer FX, Albu JB: Impaired insulin action in subcutaneous adipocytes from women with visceral obesity. Am J Physiol Endocrinol Metab 2001, 280:E40-E49.

120. Fried SK, Tittelbach T, Blumenthal J, Sreenivasan U, Robey L, Yi J, Khan S, Hollender C, Ryan AS, Goldberg AP: Resistance to the antilipolytic effect of insulin in adipocytes of African-American compared to Caucasian postmenopausal women. J Lipid Res 2010, 51:1193-1200.

121. Shadid S, Koutsari $C$, Jensen MD: Direct free fatty acid uptake into human adipocytes in vivo: relation to body fat distribution. Diabetes 2007 56:1369-1375

122. Koutsari $C$, Mundi MS, Ali AH, Jensen MD: Storage rates of circulating free Fatty Acid into adipose tissue during eating or walking in humans. Diabetes 2012, 61:329-338

123. Ali AH, Koutsari C, Mundi M, Stegall MD, Heimbach JK, Taler SJ, Nygren J, Thorell A, Bogachus LD, Turcotte LP, Bernlohr D, Jensen MD: Free fatty acid storage in human visceral and subcutaneous adipose tissue: role of adipocyte proteins. Diabetes 2011, 60:2300-2307.

124. Nielsen S, Guo Z, Ablu JB, Klein S, O'Brien PC, Jensen MD: Energy expenditure, sex, and endogenous fuel availability in humans. J Clin Invest 2003, 111:981-988.

125. Horton TJ, Pagliassotti MJ, Hobbs K, Hill JO: Fuel metabolism in men and women during and after long-duration exercise. J Appl Physiol 1998, 85:1823-1832.

126. Karpe F, Dickmann JR, Frayn KN: Fatty acids, obesity, and insulin resistance: time for a reevaluation. Diabetes 2011, 60:2441-2449.

127. Perseghin G, Scifo P, Pagliato E, Battezzati A, Benedini S, Soldini L, Testolin $G$, Del Maschio A, Luzi L: Gender factors affect fatty acids-induced insulin resistance in nonobese humans: effects of oral steroidal contraception. J Clin Endocrinol Metab 2001, 86:3188-3196.

128. Boden G, Lebed B, Schatz M, Homko C, Lemieux S: Effects of acute changes of plasma free fatty acids on intramyocellular fat content and insulin resistance in healthy subjects. Diabetes 2001, 50:1612-1617.
129. Koutsari C, Basu R, Rizza RA, Nair KS, Khosla S, Jensen MD: Nonoxidative free fatty acid disposal is greater in young women than men. J Clin Endocrinol Metab 2011, 96:541-547.

130. Marinou K, Adiels M, Hodson L, Frayn KN, Karpe F, Fielding BA: Young women partition fatty acids towards ketone body production rather than VLDL-TAG synthesis, compared with young men. Br J Nutr 2011, 105:857-865.

131. Jensen $M D$, Johnson $C M$ : Contribution of leg and splanchnic free fatty acid (FFA) kinetics to postabsorptive FFA flux in men and women. Metabolism 1996, 45:662-666.

132. Nielsen S, Guo Z, Johnson CM, Hensrud DD, Jensen MD: Splanchnic lipolysis in human obesity. J Clin Invest 2004, 113:1582-1588.

133. Wahrenberg $H$, Lönnqvist F, Arner $P$ : Mechanisms underlying regional differences in lipolysis in human adipose tissue. J Clin Invest 1989, 84:458-467.

134. Jensen MD, Cryer PE, Johnson CM, Murray MJ: Effects of epinephrine on regional free fatty acid and energy metabolism in men and women. Am J Physiol 1996, 270:E259-E264.

135. Arner $P$, Kriegholm $E$, Engfeldt $P$, Bolinder J: Adrenergic regulation of lipolysis in situ at rest and during exercise. J Clin Invest 1990, 85:893-898.

136. Burguera B, Proctor D, Dietz N, Guo Z, Joyner M, Jensen MD: Leg free fatty acid kinetics during exercise in men and women. Am J Physiol Endocrinol Metab 2000, 278:E113-E117.

137. Merimee TJ, Misbin RI, Pulkkinen AJ: Sex variations in free fatty acids and ketones during fasting: evidence for a role of glucagon. J Clin Endocrinol Metab 1978, 46:414-419.

138. Soeters MR, Sauerwein HP, Groener JE, Aerts JM, Ackermans MT, Glatz JF, Fliers E, Serlie MJ: Gender-related differences in the metabolic response to fasting. J Clin Endocrinol Metab 2007, 92:3646-3652.

139. Rebuffé-Scrive M, Andersson B, Olbe L, Björntorp P: Metabolism of adipose tissue in intraabdominal depots of nonobese men and women. Metabolism 1989, 38:453-458

140. Lönnqvist F, Thörne A, Large $V$, Arner P: Sex differences in visceral fat lipolysis and metabolic complications of obesity. Arterioscler Thromb Vasc Biol 1997, 17:1472-1480.

141. Kershaw EE, Flier JS: Adipose tissue as an endocrine organ. J Clin Endocrinol Metab 2004, 89:2548-2556.

142. Scherer PE: Adipose tissue: from lipid storage compartment to endocrine organ. Diabetes 2006, 55:1537-1545.

143. Considine RV, Sinha MK, Heiman ML, Kriauciunas A, Stephens TW, Nyce MR, Ohannesian JP, Marco CC, McKee LJ, Bauer TL, Caro JF: Serum immunoreactive-leptin concentrations in normalweight and obese humans. N Engl J Med 1996, 334:292-295.

144. Hickey MS, Israel RG, Gardiner SN, Considine RV, McCammon MR, Tyndal GL, Houmard JA, Marks RH, Caro JF: Gender differences in serum leptin levels in humans. Biochem Mol Med 1996, 59:1-6.

145. Hellström L, Wahrenberg H, Hruska K, Reynisdottir S, Arner P: Mechanisms behind gender differences in circulating leptin levels. J Intern Med 2000, 247:457-462.

146. Nagy TR, Gower BA, Trowbridge CA, Dezenberg C, Shewchuk RM, Goran MI: Effects of gender, ethnicity, body composition, and fat distribution on serum leptin concentrations in children. J Clin Endocrinol Metab 1997, 82:2148-2152.

147. Tome MA, Lage M, Camina JP, Garcla-Mayor R, Dieguez C, Casanueva FF: Gender-based differences in serum leptin levels from umbilical cord blood at delivery. Eur J Endocrinol 1997, 137:655-658.

148. Blum WF, Englaro P, Hanitsch S, Juul A, Hertel NT, Muller J, Skakkebaek NE, Heiman ML, Birkett M, Attanasio AM, Kiess W, Rascher W: Plasma leptin levels in healthy children and adolescents: dependence on body mass index, body fat mass, gender, pubertal stage, and testosterone. J Clin Endocrinol Metab 1997, 82:2904-2910.

149. Rosenbaum M, Nicolson M, Hirsch J, Heymsfield SB, Gallagher D, Chu F, Leibel RL: Effects of gender, body composition, and menopause on plasma concentrations of leptin. J Clin Endocrinol Metab 1996, 81:3424-3427.

150. Hadji P, Hars O, Bock K, Sturm G, Bauer T, Emons G, Schulz KD: The influence of menopause and body mass index on serum leptin concentrations. Eur J Endocrinol 2000, 143:55-60.

151. Arita Y, Kihara S, Ouchi N, Takahashi M, Maeda K, Miyagawa J, Hotta K, Shimomura I, Nakamura T, Miyaoka K, Kuriyama H, Nishida M, Yamashita S, Okubo K, Matsubara K, Muraguchi M, Ohmoto Y, Funahashi T, Matsuzawa Y: Paradoxical decrease of an adipose-specific protein, adiponectin, in obesity. Biochem Biophys Res Commun 1999, 257:79-83. 
152. Nishizawa H, Shimomura I, Kishida K, Maeda N, Kuriyama H, Nagaretani H, Matsuda M, Kondo H, Furuyama N, Kihara S, Nakamura T, Tochino Y, Funahashi T, Matsuzawa Y: Androgens decrease plasma adiponectin, an insulin-sensitizing adipocyte-derived protein. Diabetes 2002, 51:2734-2741.

153. Cnop M, Havel PJ, Utzschneider KM, Carr DB, Sinha MK, Boyko EJ, Retzlaff BM, Knopp RH, Brunzell JD, Kahn SE: Relationship of adiponectin to body fat distribution, insulin sensitivity and plasma lipoproteins: evidence for independent roles of age and sex. Diabetologia 2003, 46:459-469.

154. Dieudonne MN, Pecquery R, Boumediene A, Leneveu MC, Giudicelli Y: Androgen receptors in human preadipocytes and adipocytes: regional specificities and regulation by sex steroids. Am J Physiol 1998, 274:C1645-C1652.

155. Pedersen SB, Bruun JM, Hube F, Kristensen K, Hauner H, Richelsen B: Demonstration of estrogen receptor subtypes alpha and beta in human adipose tissue: influences of adipose cell differentiation and fat depot localization. Mol Cell Endocrinol 2001, 182:27-37.

156. Pedersen SB, Kristensen K, Hermann PA, Katzenellenbogen JA, Richelsen B: Estrogen controls lipolysis by up-regulating alpha2A-adrenergic receptors directly in human adipose tissue through the estrogen receptor alpha. Implications for the female fat distribution. J Clin Endocrinol Metab 2004, 89:1869-1878.

157. Dicker A, Rydén M, Näslund E, Muehlen IE, Wirén M, Lafontan M, Arner P: Effect of testosterone on lipolysis in human pre-adipocytes from different fat depots. Diabetologia 2004, 47:420-428.

158. Blouin K, Nadeau M, Perreault M, Veilleux A, Drolet R, Marceau P, Mailloux J, LuU-The $V$, Tchernof A: Effects of androgens on adipocyte differentiation and adipose tissue explant metabolism in men and women. Clin Endocrinol (Oxf) 2010, 72:176-188.

159. Perrini S, Natalicchio A, Laviola L, Belsanti G, Montrone C, Cignarelli A, Minielli V, Grano M, De Pergola G, Giorgino R, Giorgino F: Dehydroepiandrosterone stimulates glucose uptake in human and murine adipocytes by inducing GLUT1 and GLUT4 translocation to the plasma membrane. Diabetes 2004, 53:41-52.

160. Casabiell X, Piñeiro V, Peino R, Lage M, Camiña J, Gallego R, Vallejo LG, Dieguez C, Casanueva FF: Gender differences in both spontaneous and stimulated leptin secretion by human omental adipose tissue in vitro: dexamethasone and estradiol stimulate leptin release in women, but not in men. J Clin Endocrinol Metab 1998, 83:2149-2155.

161. Piñeiro V, Casabiell X, Peinó R, Lage M, Camiña JP, Menendez C, Baltar J, Dieguez C, Casanueva F: Dihydrotestosterone, stanozolol, androstenedione and dehydroepiandrosterone sulphate inhibit leptin secretion in female but not in male samples of omental adipose tissue in vitro: lack of effect of testosterone. J Endocrinol 1999, 160:425-432.

162. Xu Y, Nedungadi TP, Zhu L, Sobhani N, Irani BG, Davis KE, Zhang X, Zou F, Gent LM, Hahner LD, Khan SA, Elias CF, Elmquist JK, Clegg DJ: Distinct hypothalamic neurons mediate estrogenic effects on energy homeostasis and reproduction. Cell Metab 2011, 14:453-465.

163. Tchoukalova YD, Koutsari C, Karpyak MV, Votruba SB, Wendland E, Jensen MD: Subcutaneous adipocyte size and body fat distribution. Am J Clin Nutr 2008, 87:56-63.

164. Faust IM, Johnson PR, Stern JS, Hirsch J: Diet-induced adipocyte number increase in adult rats: a new model of obesity. Am J Physiol 1978, 235: E279-E286.

165. DiGirolamo M, Fine JB, Tagra K, Rossmanith R: Qualitative regional differences in adipose tissue growth and cellularity in male Wistar rats fed ad libitum. Am J Physiol 1998, 274:R1460-R1467.

166. Tchoukalova YD, Koutsari C, Votruba SB, Tchkonia T, Giorgadze N, Thomou $T$, Kirkland $J$, Jensen MD: Sex- and depot-dependent differences in adipogenesis in normal-weight humans. Obesity (Silver Spring) 2010, 18:1875-1880.

167. Anderson LA, McTernan PG, Barnett AH, Kumar S: The effects of androgens and estrogens on preadipocyte proliferation in human adipose tissue: influence of gender and site. J Clin Endocrinol Metab 2001, 86:5045-5051.

168. Gupta V, Bhasin S, Guo W, Singh R, Miki R, Chauhan P, Choong K, Tchkonia T, Lebrasseur NK, Flanagan JN, Hamilton JA, Viereck JC, Narula NS, Kirkland $J$, Jasuja R: Effects of dihydrotestosterone on differentiation and proliferation of human mesenchymal stem cells and preadipocytes. Mol Cell Endocrinol 2008, 296:32-40.

169. Rice SP, Zhang L, Grennan-Jones F, Agarwal N, Lewis MD, Rees DA, Ludgate M: Dehydroepiandrosterone (DHEA) treatment in vitro inhibits adipogenesis in human omental but not subcutaneous adipose tissue. Mol Cell Endocrinol 2010, 320:51-57.
170. Rantalainen M, Herrera BM, Nicholson G, Bowden R, Wills QF, Min JL, Neville MJ, Barrett A, Allen M, Rayner NW, Fleckner J, McCarthy MI, Zondervan KT, Karpe F, Holmes CC, Lindgren CM: MicroRNA expression in abdominal and gluteal adipose tissue is associated with mRNA expression levels and partly genetically driven. PLoS One 2011, 6:e27338.

171. Min JL, Nicholson G, Halgrimsdottir I, Almstrup K, Petri A, Barrett A, Travers M, Rayner NW, Mägi R, Pettersson FH, Broxholme J, Neville MJ, Wills QF, Cheeseman J, GIANT Consortium, MoIPAGE Consortium, Allen M, Holmes CC, Spector TD, Fleckner J, McCarthy MI, Karpe F, Lindgren CM, Zondervan $\mathrm{KT}$ : Coexpression network analysis in abdominal and gluteal adipose tissue reveals regulatory genetic loci for metabolic syndrome and related phenotypes. PLOS Genet 2012, 8:e1002505.

doi:10.1186/2042-6410-3-13

Cite this article as: Karastergiou et al: Sex differences in human adipose tissues - the biology of pear shape. Biology of Sex Differences 2012 3:13.

\section{Submit your next manuscript to BioMed Central and take full advantage of:}

- Convenient online submission

- Thorough peer review

- No space constraints or color figure charges

- Immediate publication on acceptance

- Inclusion in PubMed, CAS, Scopus and Google Scholar

- Research which is freely available for redistribution 